\title{
PENGARUH SUHU PADA PROSES PENGOMPOSAN PELEPAH SAWIT MENGUNAKAN ISOLAT LOKAL Pseudomonas stutzeri (LBKURCC 54 DAN LBKURCC 59)
}

\author{
Suci Apriani, Amir Awaluddin, Saryono \\ Pascasarjana Kimia, FMIPA, Universitas Riau, Pekanbaru 28293. amirawaluddin01@ gmail.com \\ e-mail: shabri_pw@yahoo.com
}

\begin{abstract}
ABSTRAK
Saat ini, pelepah kelapa sawit merupakan limbah pertanian yang belum dimanfaatkan secara optimal. Pada penelitian ini, limbah pelepah kelapa sawit dikonversi menjadi kompos dengan cara fermentasi. Proses pengomposan dilakukan menggunakan kombinasi bioaktivator lokal ditambah kotoran ayam yang berfungsi menyediakan nutrisi bagi bioaktivator. Bioaktivator sebagai starter yang digunakan merupakan kombinasi dari dua Isolat yaitu Pseudomonas stutzeri (LBKURCC 54 dan 59) yang disubkultur pada Nutrient Broth dan difermentasi selama 7 hari menggunakan media bibit. Substrat diinokulasi $10 \%$ starter dari total bahan. Untuk mempelajari kemampuan bioaktivator lokal dalam mendegradasi pelepah kelapa sawit dilakukan variasi sebagai berikut: (1) sampel dengan dan tanpa starter (2) sampel dengan dan tanpa pembalikan. Kualitas kompos terbaik yang dihasilkan dari sampel yang menggunakan starter dengan pembalikan tiga hari sekali. Nilai rasio $\mathrm{C} / \mathrm{N}$ yang merupakan indikator penentu kematangan kompos, menurun hingga akhir pengomposan dan telah sesuai dengan standar SNI yaitu 13,46 .
\end{abstract}

Kata kunci: Bioaktivator, kompos, limbah pelepah kelapa sawit, isolat Pseudomonas stutzeri (LBKURCC 54 dan 59).

\section{PENDAHULUAN}

Pelepah sawit merupakan produk perkebunan kelapa sawit yang dapat diperoleh sepanjang tahun bersamaan dengan panen tandan buah segar. Setiap pohon kelapa sawit dapat menghasilkan 22 pelepah/tahun dan rataan bobot pelepah per batang mencapai $2,2 \mathrm{~kg}$ (setelah dikupas). Selama ini pelepah kelapa sawit kurang dimanfaatkan oleh masyarakat dan lebih bersifat limbah karena biasanya hanya ditumpuk di sekitar pohon saja (Sundari S, 2012). Pelepah kelapa sawit berpotensi untuk digunakan sebagai bahan kompos. Padil (2009) melaporkan pelepah sawit memiliki komposisi selulosa 34,9 \%, hemiselulosa 27,14\% dan lignin 19,87\%.

Kesulitan yang dihadapi dalam proses degradasi lignoselulosa adalah susunan yang heterogen dari polisakarida yang terdapat pada dinding sel.Selulosa merupakan polimer linier dari D-glukosa yang terikat pada ikatan 1,4 $\beta$ glikosidik dan sangat erat berasosiasi dengan hemiselulosa dan lignin. Meskipun demikian, diperlukan upaya untuk mendegradasi ketiga komponen dengan cepat. Proses degradasi dapat dipercepat dengan adanya bakteri yang dapat menghasilkan enzim selulosa, sehingga komponen selulosa dapat dihidrolisis.

Agar penguraian pelepah kelapa sawit dapat efektif, maka mikroba pengurai membutuhkan nutrien yang memadai. Kotoran ayam dapat dijadikan sebagai sumber nutrien karena mengandung unsur hara yang relatif tinggi, seperti kandungan N: 1,0 \%; P: 9,5\%; dan K: 0,3 (Setiawan, 2005).

Enzim selulase adalah suatu enzim yang mampu menguraikan selulosa dengan cara menghidrolisis ikatan $\beta-1,4$ glikosidik menjadi bentuk yang lebih sederhana yaitu monomer glukosa (Acharya dkk, 2008). Bakteri endofit LBKURCC54 dan LBKURCC59 merupakan isolat bakteri koleksi Laboratorium riset enzim, fermentasi dan biomolekuler FMIPA UR yang diisolasi dari umbi tanaman dahlia. Hasil penelitian Marlinda (2013) mendapatkan aktivitas selulolitik LBKURCC 54 dan LBKURCC 59 sebesar 1,85 x 10-2 U/mg dan 3,6 
$\mathrm{x} \quad 10^{-2} \mathrm{U} / \mathrm{mg}$, sehingga diharapkan dapat mempercepat pross degradasi selulosa pada pelepah sawit.

\section{METODOLOGI PENELITIAN}

\section{Alat dan Bahan}

Alat-alat yang akan digunakan dalam penelitian ini meliputi Spektrofotometer UV-Vis (Spektronic thermo sciencetific genesys D 20), Flame Fotometer (Jenway Series PFP 007), Neraca Analitik (Mettler tipe AE200), Oven (Gallenkamp), Furnace (Gallenkamp muffle furnace), $\mathrm{pH}$ meter (Orion $210 \mathrm{~A}$ ), penangas air, autoklaf, cawan petri, tabung reaksi, erlenmeyer, beaker glass, microwave, rotary shaking incobator.

Bahan-bahan yang digunakan dalam penelitian ini adalah pelepah kelapa sawit yang telah di cacah, kotoran ayam, koleksi bakteri LBKURCC 54 dan LBKURCC59, serbuk NA, serbuk $N B, \mathrm{KH}_{2} \mathrm{PO}_{4}, \mathrm{FeSO}_{4}, \mathrm{~K}_{2} \mathrm{SO}_{4}, \mathrm{MgSO}_{4}$, akuades, alkohol, $\mathrm{K}_{2} \mathrm{Cr}_{2} \mathrm{O}_{7}, \mathrm{H}_{2} \mathrm{SO}_{4}$ pekat, larutan buffer, $\mathrm{HCl}$ pekat, $\mathrm{HNO}_{3}$, dedak, terasi dan gula merah

\section{Rancangan Penelitian}

Penelitian ini merupakan Rancangan Petak Petak Terbagi (RPPT). Penelitian ini terdiri dari beberapa tahap, Tahap I yaitu: persiapan kultur starter dan persiapan alat dan bahan. Tahap II yaitu Pengomposan pelepah kelapa sawit dilakukan dengan mencacahpelepah kelapa sawit dengan ukuran $\pm 5 \mathrm{~cm}$, kemudian dibuat menjadi
2 tumpukan dengan ukuran $20 \times 20 \times 30 \mathrm{~cm}$ yang dibagi masing-masing 3 tumpukan. 3 tumpukan pertama, terdiri dari $9 \mathrm{~kg}$ campuran pelepah kelapa sawit ditambah kotoran ayam dan air dengan perbandingan 2:1. Tiga tumpukan kedua masing-masing terdiri dari $9 \mathrm{~kg}$ campuran pelepah kelapa sawit ditambah kotoran ayam, tambah starter. Tahap III adalah penanganan terhadap sampel kompos, dilakukan variasi waktu pembalikan, yaitu tanpa pembalikan (PA 0 dan PB 0), pembalikan setiap tiga hari sekali (PA 3 dan PB 3) dan pembalikan setiap enam hari sekali (PA 6 dan PB 6). Pengukuran temperatur dilakukan setiap hari selama 21 hari untuk sampel P 0 dan P 3, dan selama 24 hari untuk sampel $P$ 6. Tahap IV adalah analisis sampel melalui analisa kadar unsur karbon organik, nitrogen total dan rasio $\mathrm{C} / \mathrm{N}$.

\section{HASIL DAN PEMBAHASAN Penentuan temperatur}

Proses perubahan temperatur pada pengomposan pelepah kelapa sawit terlihat pada gambar 1.

Terjadi peningkatan temperatur yang cukup tajam setelah 24 jam pengomposanyaitu 40-42,83 ${ }^{\circ} \mathrm{C}$. Temperatur pengomposan tertinggi terdapat pada PB-6 yaitu $42,83 \quad{ }^{\circ} \mathrm{C}$. Temperatur mengalami penurunan perlahan-lahan sejak hari ke lima. Temperatur pengomposan tidak berubah sejak hari ke 19 proses pengomposan.

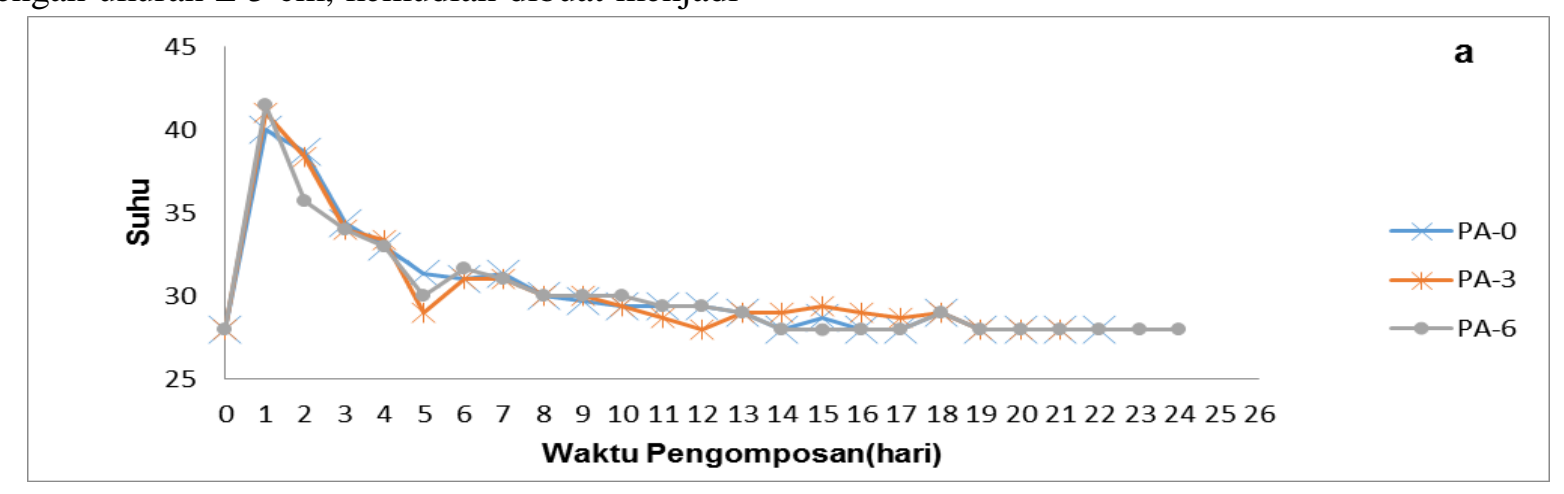




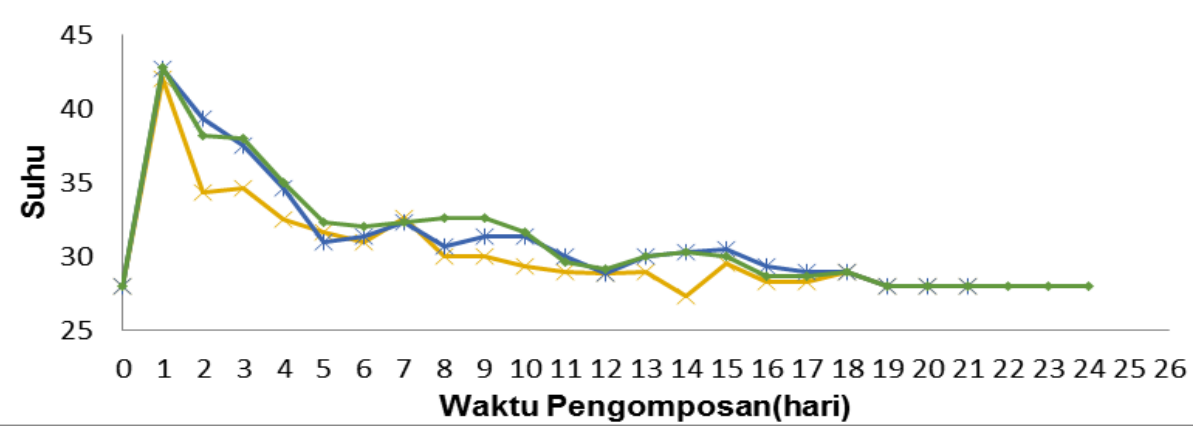

b

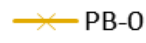

* $\mathrm{PB}-3$

Gambar 1. Grafik hubungan waktu pengomposan, starter dan variasi waktupembalikan terhadap temperatur; a) sampel PA, b) sampel PB.

Peningkatan temperatur menunjukkan terjadi aktivitas mikroorganisme dalam pemutusan berbagai ikatan pada selulosa menjadi yang lebih sederhana, yaitu gas $\mathrm{CO}_{2}$, air, dan panas. Tinggi tumpukan dan ukuran partikel juga mempengaruhi peningkatan temperatur pada substrat. Temperatur pada sampel PB, yaitu bahan yang ditambah dengan starter lebih tinggi $\left(42,67^{\circ} \mathrm{C}\right)$ dari pada sampel PA, bahan yang tidak ditambah dengan starter $\left(41,{ }^{\circ} \mathrm{C}\right)$. Hal ini karena mikroorganisme yang berperan dalam proses pendegradasian bahan organik pada sampel PB lebih banyak.

Temperatur kompos mulai mendekati temperatur ruang, sejak hari ke 19. Temperatur yang dicapai yakni $28{ }^{\circ} \mathrm{C}$. Dalam kondisi temperatur kompos yang telah mencapai kisaran temperatur lingkungan ideal yakni $25-28{ }^{\circ} \mathrm{C}$ (Sutanto, 2002), maka kompos dikatakan berada pada tahap pematangan.

Kajian proses pengomposan peneliti terdahulu terhadap penentuan temperatur, pada pengomposan dari jerami dengan inokulan konsorsium dekomposer beragen hayati mendapatkan nilai temperatur masih tinggi pada hari ke 28 , yaitu sebesar $43-57{ }^{\circ} \mathrm{C}$ (Tien dkk, 2011), namun pada pengomposan dari limbah sludge pabrik kertas nilai temperatur mendekati normal yaitu $29^{\circ} \mathrm{C}$ (Hilda, 2013).

\section{Pengukuran kadar Nitrogen total}

$\mathrm{N}$-total selama pengomposan seperti yang tersaji pada Gambar 2.

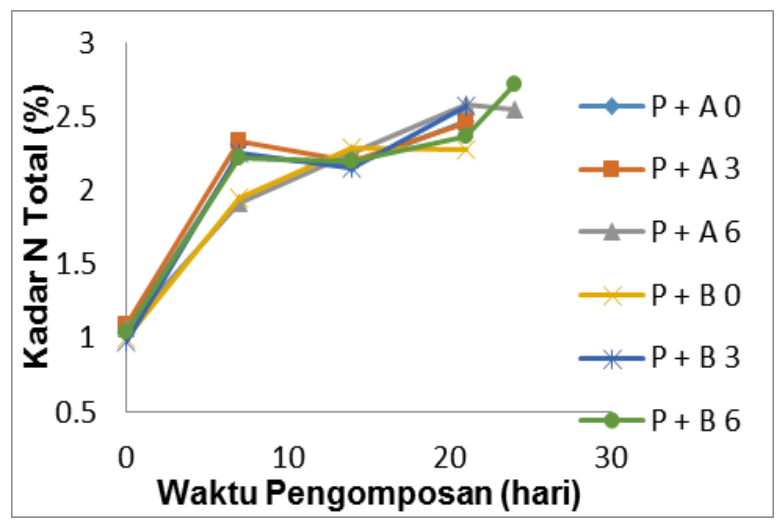

Gambar 2. Grafik hubungan waktu pengomposan, starter dan pembalikan terhadap kadar $\mathrm{N}$ total

$\mathrm{N}$-total mengalami peningkatan cukup tinggi pada minggu pertama dan sedikit menurun pada minggu kedua dan kembali meningkat pada minggu ketiga hal ini didapati pada sampel PA dan PB. Nilai N-total tertinggi pada minggu pertama terdapat pada sampel PB, yaitu 2,259\%. Namun pada sampel PA6, nilai N-total mengalami kenaikan hingga minggu ketiga dan mengalami penurunan pada minggu keempat. Penurunan terjadi akibat adanya proses denitrifikasi. Proses denitrifikasi merupakan reaksi reduksi nitrat menjadi gas $\mathrm{N}_{2}$ yang kemudian mengalami penguapan ke atmosfer. Proses ini terjadi pada kondisi reduksi sehingga dilakukan oleh organisme anearobik yang menggunakan nitrat sebagai pengganti oksigen dalam respirasinya.

Nilai kandungan N-total pada sampel diduga berasal dari kandungan $\mathrm{N}$ dari protein pelepah kelapa sawit dan penguraian protein oleh bakteri. Menurut Pratiwi (2008) dinding sel bakteri menggandung $\mathrm{N}$-asetilglukosamin dan $\mathrm{N}$ - 
asetilmuramat, sehingga kandungan $\mathrm{N}$-total juga diduga berasal dari dinding sel bakteri yang lisis.

Kadar N, melihatkan adanya perbedaan nyata $(\mathrm{P}>0,05)$ dengan lama fermentasi, tapi tidak berbeda nyata $(\mathrm{P} \leq 0,05)$ dengan variasi waktu pembalikan. Hasil $\mathrm{N}$ yang cukup tinggi didapat Kananam dkk (2011), yang melakukan pengomposan dengan TKKS, Decanter Sludge dan kotoran ayam, yaitu 2,06 \% .

Nilai N-total pada sampel PA 3 dan PB 3 berturut-turut adalah $2,457 \%, 2,358 \%$. Hal ini cukup tinggi dari nilai tandar SNI, yaitu $0,4 \%$.

\section{Pengukuran kandungan C- organik}

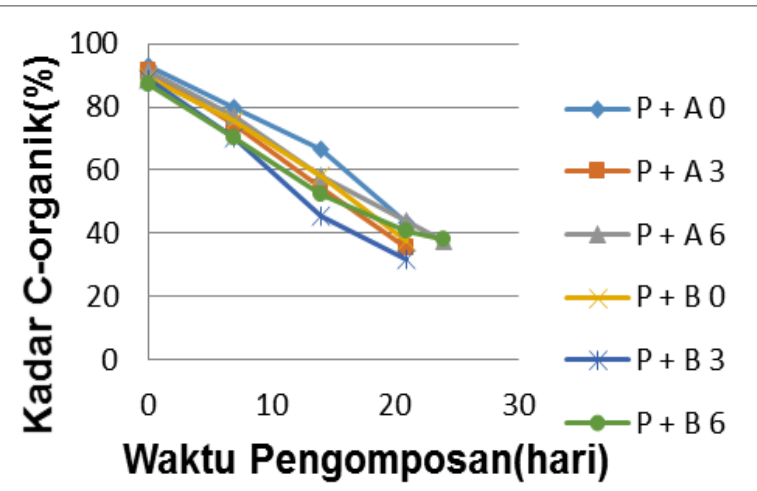

Gambar 3.Grafik hubungan waktu pengomposan, starter dan pembalikan terhadap kadar C-organik

Penurunan kandungan karbon organik mulai terjadi pada minggu pertama hingga akhir pengomposan seperti terlihat pada Gambar 3. Hal ini disebabkan karena adanya aktivitas mikroorganisme yang membutuhkan karbon organik sebagai sumber makanan yang selanjutnya akan diuraikan menjadi senyawa yang lebih sederhana. Pada saat dekomposisi akan terjadi pelepasan $\mathrm{CO}_{2}$ dan $\mathrm{H}_{2} \mathrm{O}$ ke udara yang ditandai dengan mengembunnya plastik.

Kadar karbon organik PA 3 dan PB 3 menunjukkan hasil terendah, yaitu sebesar 35.40 $\%$ dan $31,70 \%$. Kananam dkk (2011) menyatakan degradasi karbon pada kondisi aerobik lebih tinggi (30 menjadi $18 \%$ ) dari pada kondisi anaerobik (33 menjadi $29 \%$ ). Hal ini juga terlihat pada sampel dengan pembalikan tiga hari sekali, penurunan kadar karbon organik selama proses pengomposan signifikan dan lebih cepat dibandingkan dengan tanpa pembalikan dan pembalikan enam hari sekali, dimana suplai udara yang masuk lebih sedikit dari pada sampel P3. Hasil ini lebih rendah jika dibandingkan dengan penelitian yang dilakukan oleh Yeoh et al., (2012) yakni $47 \%$ pada hari ke 35 pengomposan.

Kadar C, melihatkan adanya perbedaan nyata $(\mathrm{P}>0,05)$ dengan lama fermentasi dan variasi waktu pembalikan.

Tabel 1. Hasil penentuan kandungan karbon organik, N-tot dan rasio $\mathrm{C} / \mathrm{N}$ pada fermentasi

\begin{tabular}{|c|c|c|c|}
\hline $\begin{array}{c}\text { Waktu } \\
\text { Fermentasi }\end{array}$ & $\begin{array}{c}\text { Kadar C } \\
(\%)\end{array}$ & $\begin{array}{c}\text { Kadar N } \\
(\%)\end{array}$ & Kadar C/N \\
\hline H 0 & $90.163 \mathrm{a}$ & $1.035 \mathrm{c}$ & $87.89 \mathrm{a}$ \\
\hline H 7 & $74.561 \mathrm{~b}$ & $2.225 \mathrm{~b}$ & $33.83 \mathrm{~b}$ \\
\hline H 14 & $55.975 \mathrm{c}$ & $2.210 \mathrm{~b}$ & $25.46 \mathrm{c}$ \\
\hline H 21 & $38.842 \mathrm{~d}$ & $2.454 \mathrm{a}$ & $16.07 \mathrm{~d}$ \\
\hline
\end{tabular}

Catatan:*) Pangkat huruf yang sama pada satu kolom menyatakan tidak berbeda secara signifikan pada tingkat $5 \%(\mathrm{p} \leq 0,05)$ berdasarkan uji Duncan jarak berganda

Tabel 2. Hasil rataan kandungan karbon organik, $\mathrm{N}$-tot dan rasio $\mathrm{C} / \mathrm{N}$ pada Variasi waktu pembalikan

\begin{tabular}{|c|c|c|c|}
\hline Perlakuan & $\begin{array}{c}\text { Kadar C } \\
(\%)\end{array}$ & $\begin{array}{c}\text { Kadar N } \\
(\%)\end{array}$ & $\begin{array}{c}\text { Kadar } \\
\text { C/N }\end{array}$ \\
\hline P 0 & $67.9329 \mathrm{a}$ & $1.920 \mathrm{a}$ & $43.26 \mathrm{a}$ \\
\hline P 3 & $61.5188 \mathrm{c}$ & $2.009 \mathrm{a}$ & $39.17 \mathrm{~b}$ \\
\hline P 6 & $65.2005 \mathrm{~b}$ & $2.013 \mathrm{a}$ & $40.01 \mathrm{~b}$ \\
\hline
\end{tabular}

Catatan:*) Pangkat huruf yang sama pada satu kolom menyatakan tidak berbeda secara signifikan pada tingkat $5 \%(\mathrm{p} \leq 0,05)$ berdasarkan uji Duncan jarak berganda

\section{Pengukuran rasio $\mathrm{C} / \mathrm{N}$}

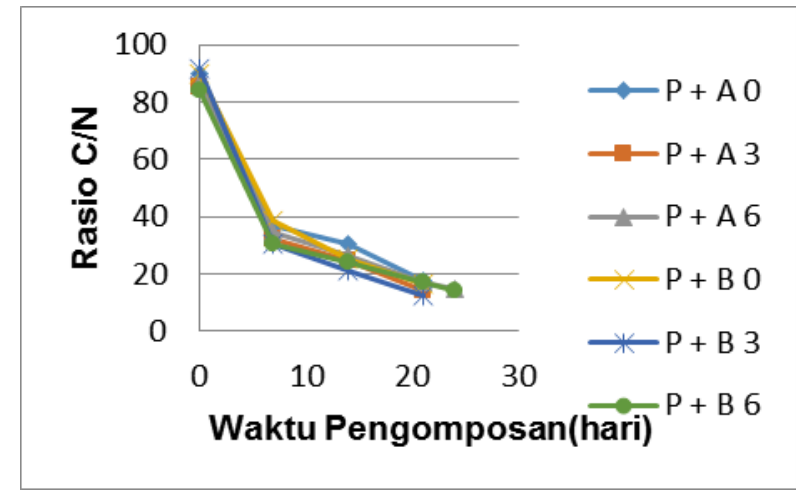

Gambar 4. Grafik hubungan waktu 
pengomposan, starter dan pembalikan terhadap rasio $\mathrm{C} / \mathrm{N}$

Kualitas akhir kompos dapat dilihat dari beberapa faktor termasuk rasio $\mathrm{C} / \mathrm{N}$ yang juga menentukan umur dan tingkat kematangan kompos. Hasil akhir nilai kompos yang didapatkan telah mencapai minimal standar rasio C/N yang ditentukan oleh SNI (10-20), yakni berkisar antar rentang 13-17\% (Gambar 4).

Hasil analisis variasi waktu pembalikan PA dan PB tidak terpisah oleh uji ANOVA pada RPPT ini, hanya ada variasi waktu pembalikan (P). Hal ini karena uji statistik variasi starter pada kadar $\mathrm{C}, \mathrm{N}$ dan rasio $\mathrm{C} / \mathrm{N}$ menunjukkan bahwa $\mathrm{t}_{\text {hitung }}<\mathrm{t}_{\text {tabel }}$ artinya tidak terdapat perbedaan nyata dari kadar $\mathrm{C}, \mathrm{N}$ dan rasio $\mathrm{C} / \mathrm{N}$ substrat pelepah sawit yang difermentasi dengan kotoran ayam dan rasio $\mathrm{C} / \mathrm{N}$ substrat pelepah sawit yang difermentasi kotoran ayam ditambah starter (LBKURCC 54 dan LBKURCC 59).

Waktu merupakan variabel yang penting pada proses pengomposan. Pada penelitian ini, hari ke tujuh pengomposan rasio $\mathrm{C} / \mathrm{N}$ masih diatas standar SNI yaitu 30-36, hal ini disebabkan degradasi bahan organik membutuhkan waktu yang cukup lama, hasil yang sama dilakukan oleh Sundari (2012) pada pengomposan pelepah dengan EM4, rasio C/N masih tinggi 43,81 dan belum memenuhi standar SNI, hal ini karena waktu pengomposan yang singkat, yaitu hanya berlangsung selama 7 hari. Namun, pada pengomposan TKKS + POME Sludge oleh Zainudin(2013), dan Mulsa pohon kurma + pupuk kandang sapi oleh Sadik (2012) nilai rasio $\mathrm{C} / \mathrm{N}$ telah memenuhi standar SNI yaitu 10-20\%, hal ini dikarenakan waktu pengomposan yang berlangsung cukup lama yaitu berkisar antara 4 hingga 12 minggu.

Penurunan rasio $\mathrm{C} / \mathrm{N}$ yang cukup signifikan disebabkan oleh berbagai faktor, pertama ukuran partikel, karena sebelum pengomposan, pelepah sawit dicacah dahulu sehingga ukurannya menjadi $\pm 5 \mathrm{~cm}$, kedua tumpukan dibuat meninggi dan yang ketiga aktivitas mikroorganisme. Faktor ini menyebabkan temperatur pengomposan menjadi tinggi. Selain itu, kadar air pada awal pengomposan berkisar
$30-40 \%$, ini baik untuk pertumbuhan mikroorganisme, penambahan kotoran ayam sebagai sumber nitogen dan pemberian starter serta waktu pengomposan yang tidak terlalu singkat.

Kadar $\mathrm{C} / \mathrm{N}$, melihatkan adanya perbedaan nyata $(\mathrm{P}>0,05)$ dengan lama fermentasi dan variasi waktu pembalikan.

\section{KESIMPULAN}

Pengomposan dari campuran limbah pelepah kelapa sawit dan kotoran ayam tidak memberikan perbedaan nyata terhadap variasi dengan penambahan aktivator. Variasi waktu pembalikan memberikan perbedaan nyata terhadap kadar $\mathrm{C}$ dan $\mathrm{C} / \mathrm{N}$

\section{DAFTAR PUSTAKA}

Acharya, P. B., Modi, H. A. 2008. Optimization for cellulase production by Aspergillus niger using saw dust as substrate. African Journal of Biotechnology. Vol 7 (22):4147-4152.

Hilda Chalimatus. 2013. Efektifitas jamur trichoderma harzianum dalam pengomposan limbah sludge Pabrik kertas. Indo. J. Chem. Sci. 2

Kananam, wathida, Thunwadee T.S., Chaisri S., 2011, Biochemical changes during oil Palm (Elaeisguineensis) empty fruit bunches composting with decanter sludge and chicken manure, ScienceAsia

Padil dan Yelmida, 2009, Produksi NitroSelulosa Sebagai Bahan Baku Propelan yang Berbasis Limbah Padat Sawit, Laporan Penelitian Hibah Penelitian Stranas Batch II, UniversitasRiau

Pratiwi, S. T. 2008. Mikrobiologi Farmasi. Erlangga, Jakarta.

Rynk, R. 1992. On-Farm Composting Handbook. Northeast Regional Agricultural Engineering Service Pub. No. 54. Cooperative Extension Service. Dilihat 13 Juni $2014 . \quad<$ http://www. nraes.org/nra_order.taf?_function=detail\& pr_id=60\&_UserReference $=$ CC61DDB3C C09FC464F347DBF> 
Sadik, M.W, Al Ashhab, Zahran M.K, Alsaqan., 2012, Composting mulch of date palm trees through microbial activator in Saudi Arabia, International Journal of Biochemistry and Biotechnology, International Scholars Journals.

Setiawan, I.S. 2005. Memanfaatkan Kotoran Ternak. Penebar Swadaya. Jakarta

Sundari S. 2012. Pengaruh Pemberian Kompos Pelepah Kelapa Sawit Dengan Berbagai Dekomposer Terhadap Pertumbuhan Dan Hasil Tanaman Pakchoy (Brassica chinensis L). Faculty of Agriculture, University of Riau

Sutanto, R. 2002. Pertanian Organik: Menuju Pertanian Alternatif dan Berkelanjutan. Penerbit; Kanisius, Yogyakarta

Tien T, Tualar S, Betty N. 2011. Pengujian inokulan konsorsium dekomposer beragen hayati dalam laju dekomposisi jerami selama masa inkubasi yang dilakukan di rumah kaca, CEFARS: Jurnal Agribisnis dan Pengembangan Wilayah Vol. 2 No. 2

Marlinda S. 2013. Uji Aktivitas dan Aktivitas Spesifik Ekstrak Kasar Enzim Selulolitik dari Beberapa Bakteri Endofit Umbi Tanaman dahlia. Pekanbaru; Skripsi FMIPA UR

Yeoh, C. Y., Chin, N. L., Tan, C. S., Ooi, H. S. 2012. Industrial scale co-composting of palm oil mill waste with starter cultures. Journal of Food, Agriculture and Environment. 10: 771-775.

Zainuddin, Hassan, Tokura., 2013, Indigenous cellulolytic bacteriaenchanced rapid cocomposting of lignocellulose oil palm empty fruit bunch with palm oil mill effluent anaerobic sludge, Bioresour Technol. 